

\section{Unravelling Travelling}




\section{THE TOURIST EXPERIENCE}

\section{Series editor: Richard Sharpley}

The Tourist Experience series addresses a notable gap in the literature on Tourism Studies by foregrounding the tourist experience in a cohesive and thematically structured manner.

Taking a novel approach by presenting both short-form publications and longform monographs exploring issues in the tourist experience, the series will seek to build a comprehensive set of texts that collectively contribute to critical discourse and understanding of the contemporary tourist experience. Short-form publications will review specific types of tourist by focusing primarily on the influences and nature and significance of their experiences within a sociocultural framework while longer titles will embrace contemporary empirical and conceptual perspectives and debates as a means of understanding experiences.

\section{Recent volumes:}

The Adventure Tourist: Being, Knowing, Becoming Dr Jelena Farkić and Dr Maria Gebbels

\section{Forthcoming Volumes:}

The Responsible Tourist: Conceptualizations, Expectations and Dilemmas Dirk Reiser and Volker Rundshagen

The Sport Tourist

Sean James Gammon

The Mindful Tourist: The Power of Presence in Tourism Uglješa Stankov, Ulrike Gretzel and Viachaslau Filimonau 


\section{Unravelling Travelling: Uncovering Tourist Emotions through Autoethnography}

BY

\section{SUE BEETON}

Independent Researcher, Australia

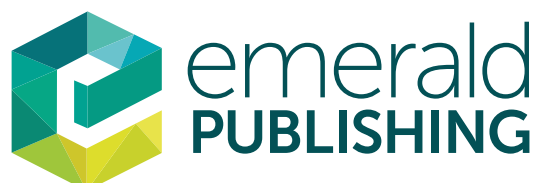


Emerald Publishing Limited

Howard House, Wagon Lane, Bingley BD16 1WA, UK

First edition 2022

Copyright (C) 2022 Sue Beeton. Published under exclusive license by Emerald Publishing Limited.

\section{Reprints and permissions service}

Contact: permissions@emeraldinsight.com

No part of this book may be reproduced, stored in a retrieval system, transmitted in any form or by any means electronic, mechanical, photocopying, recording or otherwise without either the prior written permission of the publisher or a licence permitting restricted copying issued in the UK by The Copyright Licensing Agency and in the USA by The Copyright Clearance Center. Any opinions expressed in the chapters are those of the authors. Whilst Emerald makes every effort to ensure the quality and accuracy of its content, Emerald makes no representation implied or otherwise, as to the chapters' suitability and application and disclaims any warranties, express or implied, to their use.

\section{British Library Cataloguing in Publication Data}

A catalogue record for this book is available from the British Library

ISBN: 978-1-80117-180-9 (Print)

ISBN: 978-1-80117-179-3 (Online)

ISBN: 978-1-80117-181-6 (Epub) 


\section{Contents}

List of Tables $\quad$ X

List of Figures $\quad$ xi

About the Author xii

Acknowledgements xiii

Introduction

\section{Section One: The Theory}

Chapter One From Experiences To Emotions 5

$\begin{array}{ll}\text { The Tourist Experience } & 6\end{array}$

The Tourist Experience as Emotional Experience 8

Digression 1: On Seeing Uluru 9

Digression 2: On the Chorister 13

The Role of Memory and Recall in the Tourist Experience 13

$\begin{array}{ll}\text { The Emotional Tourist } & 16\end{array}$

Chapter Two The Self As Data: Autoethnography 21

Digression 3: On Flâneusing $\quad 21$

Development of Autoethnography as a Research Method 23

Evocative, Performance or Analytical Autoethnography? 25

Evocative Autoethnography 26

Performance Autoethnography $\quad 29$

Analytical Autoethnography 33

Illustrating the Power of Autoethnography 34

Criticisms, Challenges and Concerns $\quad 37$

The Ethics of Autoethnography 40

Assessing Autoethnography 41 
Chapter Three Autoethnography in Travel and Tourism

Autoethnography in Leisure

Autoethnography in Travel and Tourism

The Naming of Autoethnography in Travel and Tourism

Research

Analytical Autoethnography in Travel and Tourism 53

Digression 4: On Literature Reviews 56

Evocative Travel and Tourism Autoethnographies $\quad 57$

Collaborative Autoethnography $\quad 58$

Digression 5: On Theory $\quad 59$

My Early Travel and Tourism Autoethnographies 59

Quality of Travel and Tourism Autoethnographies 61

My Touristic Journeys Presented in This Book 61

$\begin{array}{lll}\text { Chapter Four The Story So Far } & 65\end{array}$

Tourist Experiences and Emotions $\quad 65$

Memory and Recall 66

Tourist Emotions $\quad 67$

Autoethnography and Tourism 68

Evocative, Performance and Analytical Autoethnography 68

Autoethnography in Leisure, Travel and Tourism 69

$\begin{array}{ll}\text { Bringing It All Together } & 70\end{array}$

Criticisms of and Assessing Autoethnography 71

\section{Section Two: The Stories}

$\begin{array}{ll}\text { Chapter Five An Unlikely Pair? } & 75\end{array}$

Inside-Out: My Place, My Culture 76

Why Go There? $\quad 78$

Why Return? $\quad 82$

On Solo Travelling $\quad 83$

The Stories $\quad 83$

Something's Missing ... $\quad 84$

$\begin{array}{lll}\text { Chapter Six } & \text { My Stories } & 87\end{array}$

Story One: From a Crooked Angle $\quad 89$

India $\quad 89$

$\begin{array}{ll}\text { Japan } & 90\end{array}$ 
Looking from a Crooked Angle $\quad 92$

Story Two: Beyond Tired ... 93

Story Three: The Guest $\quad 94$

Story Four: Portals to the Past 99

The Nakasendo Way - Treading the Path of Emperors 99

The Marwari Horse - Riding the Path of the Warriors $\quad 100$

Story Five: Sacred Travels: A Clearing in the Wilderness 101

Story Six: Born and Reborn - The Child and the Traveller 107

Story Seven: I Was Ready to Scream 109

Story Eight: It's All Arranged ... 113

Story Nine: Taking It Slow $\quad 118$

Story Ten: The Animals of Rajpur - Trauma and Healing in India 122

Story Eleven: Oblique Obsessions 126

Story Twelve: Frisson, Shivers and Slivers 129

Story Thirteen: "They Came From the Stars" 130

Story Fourteen: Can it Really Be? Creating Impossible Places 134

Story Fifteen: Little Lies ... 137

Story Sixteen: Watching the Watchers Watching Me - India's

Last Lesson? 140

Story Seventeen: Aloha 143

Story Eighteen: Grounding My Emotions 146

Section Three: What Does It Mean?

Chapter Seven Analytical Autoethnographic Process 151

Grounded Theory $\quad 152$

Text Analysis 153

Content Analysis $\quad 154$

Thematic and Contextual Identification 155

Reflective or Reflexive Analysis? $\quad 156$

Analytical Process 157

Inferred Emotions 158

Theoretical Modelling $\quad 159$

Chapter Eight Analytical Autoethnography Outcomes 161

Keywords and Themes $\quad 162$

Inferred Emotions 164

$\begin{array}{ll}\text { Emotional Connection } & 169\end{array}$

Connected to People 169

$\begin{array}{ll}\text { Connected to a Culture } & 170\end{array}$ 
Connected to Land $\quad 170$

Connected to the Past 171

Emotional Disconnection $\quad 171$

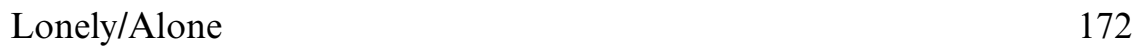

Confused/Conflicted 173

Connected and Disconnected 173

Deep Awe/Numinousity $\quad 174$

Theoretical Models $\quad 175$

Graphic Models: The Continuum 175

Graphic Model: Connectedness 177

The Descriptive Model: The Seeker 178

From Telling to Showing: Analytical to Evocative

Autoethnography 180

Chapter Nine Evocative Autoethnography Outcomes A Debate With Myself

181

Section Four: Conclusion

$\begin{array}{ll}\text { Chapter Ten Assessing Autoethnography } & 193\end{array}$

On Becoming an Autoethnographic Researcher 193

Reflexive Analysis of the Methodological Process 197

Quality of My Research 198

Responsibility 198

Data Must Be Authentic and Trustworthy 199

Ethical Approach 199

Contribution to Knowledge 199

Demonstrating the Power of Stories 199

Valuing the Personal and Experiential 199

Sociocultural Meanings Analysed 199

The Case for Autoethnography in Tourism Research 200

$\begin{array}{ll}\text { A Warning } & 200\end{array}$

A Final Digression? 201

$\begin{array}{ll}\text { Chapter Eleven So What? } & 203\end{array}$

The Analytical Models 203

The Graphic Models 204

The Descriptive Model 205

The Emotional Tourist 205

An Evocative Conclusion? 205 
Bringing it Home: The Role of Emotions in the Tourist Experience

Generalisability of the Finding 208

My Contribution (to Theory and Knowledge)

Afterword

References

Index 


\section{List of Tables}

Table 1. Emotional Themes and Words. 163

Table 2. Inferred Emotional Themes. 168

Table 3. Personal Research Development. 195 


\section{List of Figures}

Figure 1. The Distinctive Ears of the Marwari Horse. 79

Figure 2. My Jizō Protectors. $\quad 103$

Figure 3. The Ganga Aarti. 105

Figure 4. The Bejewelled Marwari Horse and Bridegroom. 114

Figure 5. My Black Sari and Dancing Horse, Chirmi. 115

Figure 6. The Slowest Food in Japan: Katsuobushi. 120

$\begin{array}{ll}\text { Figure 7. Puppy. } & 123\end{array}$

Figure 8. Pony. 125

Figure 9. Japanese Manhole Covers. 127

Figure 10. Giving My Goat Away. 131

Figure 11. Hogwarts Castle Japan. 136

Figure 12. Coco Palms Legend, Larry Rivera. 144

Figure 13. Travel Emotions (Stated and Inferred). 175

Figure 14. The Emotional Ecosystem. 176

$\begin{array}{ll}\text { Figure 15. Model of Connectedness. } & 177\end{array}$

Figure 16. Personal Research Tree Rings. 194 


\section{About the Author}

Prof Beeton is a Travel and Tourism Researcher and Writer who became involved in tourism in the late 1980s through guiding horseback tours in the mountains, many of which were themed around the movie, The Man from Snowy River environments, and wrote her first book on adventure horse riding. Here she witnessed the growth of tourism and its effects on small, local communities as well as fragile alpine environments. For over a quarter of a century, she has conducted tourismbased research into community development and public land management, along with film-induced tourism and pop culture's relationship with travel and tourism. As well as producing numerous academic papers, book chapters and reports, she has published a range of research-based books on those topics, along with developing her interest in autoethnographic research.

She is a Visiting Professor at the University of Hokkaido, and in 2019, she was awarded the TTRA Lifetime Achievement Award for her contribution to tourism research and scholarship. 


\section{Acknowledgements}

I wish to acknowledge the traditional custodians of the land on which I live and have written this book, The Wathaurong and Yorta Yorta peoples of the Kulin Nation. Cover artwork is a representation of Jizō, a Japanese deity who is the guardian of 'lost' children and travellers. They are often found in temples and along sacred walking trails wearing red bibs and hoods, where travellers and parents leave small gifts of coin, food and toys. 